\title{
Formulation of Allium sativum L. and Melia azedarach L. plant extracts and their effects on Myzus persicae Sulzer, 1776 (Hemiptera:Aphididae)
}

\begin{abstract}
Myzus persicae Sulzer, 1776 (Hem.: Aphididae) the most important pests of vegetable cultivated in the world. Pesticides are used extensively to control this pest. Intensive use of chemical pesticides to control pests caused various side effects such as residues in the product, pests' resistance and push a great risk for human health, nature and environment. This study was undertaken to provide an alternative to chemical pesticides. For this purpose, the extract of Allium sativum L. (Liliaceae) and Melia azedarach L. (Meliaceae) were prepared. Then formulation studies of these extracts were carried out with several inert ingredients. Obtained preparations were subjected to quality control tests in the laboratory. As a result of these tests, preparations which were found successfully were separated/ chosen for effectiveness studies on $M$. persicae. According to the results of laboratory studies, the highest dose found to be effective and theirs two upper doses $(10,15,20 \mathrm{ml} / \mathrm{L})$ were taken to examine effect on $M$. persicae at the greenhouse conditions. The trial was established as randomized block design and 5 times in greenhouse. Commercial product Neem Azal T/S was used as positive control. The results of the greenhouse trials revealed that the insecticidal effect of $M$. azederach and A. sativum plants extract were $90.33 \%$ and $79.50 \%$ respectively. Also, it was determined that the insecticidal effect of $M$. azederach plant extract and Neem Azal T/S were $94.38 \%$ and 92.81 respectively.
\end{abstract}

Keywords: green peach aphid, plant extracts, formulations, insecticidal effect
Volume 8 Issue 3 - 2020

\section{Pervin ERDOGAN,' Pelin AKSU, ${ }^{2}$ Gamze ESIN KILINC, ${ }^{2}$ Murat KAHYAOGLU, ${ }^{3}$ Numan E BABAROGLU ${ }^{2}$}

'Department of Plant Protection, Sivas Science and Technology University, Turkey

${ }^{2}$ Plant Protection Central Research Institute, Turkey

${ }^{3}$ Agriculture and Chemical industry Trade Corporation, Turkey

Correspondence: Pervin ERDOGAN, Department of Plant Protection, Faculty of Agricultural Sciences and Technology, Sivas Science and Technology University, Turkey, Tel +90346 21913 98, Fax+903462191678, Email pervinerdogan@sivas.edu.tr

Received: August 05, 2020 | Published: August 19, 2020

\section{Introduction}

Vegetable cultivation is carried out in almost every both greenhouse and field condition and constitutes $95 \%$ of the total greenhouse cultivation in our country. Generally, white flies, aphids and red spiders cause significant loss of crops in vegetable cultivation. Myzus persicae Sulzer (Hem.: Aphididae) which is harmful in vegetables. M. persicae usually feeds on fresh shoots of the plant and weakens the growth of the plant. It is also the vector of some virus diseases. ${ }^{1}$ Chemical pesticides are used to control both pests and consumption of chemical pesticides is increasing day by day. Chemical pesticides used intensively and unconsciously especially in greenhouse vegetable growing caused residues in the product, resistance to pests and constitutes a great risk for human health, nature and environment. It also creates an important problem in vegetable exports. Due to the damage of chemical pesticides, researchers have to search for alternative methods to control harmful pests. Based on these researchers have focused on different control methods. Biopesticides are derived from such natural materials as animals, plants, bacteria. Most work on this subject has been carried out on plants. Plants have been used in pest control since ancient times. The ancient Romans with the use of insecticide-containing olive oil and hellebore plants ${ }^{2}$ conducted the first application. The use of biopesticides in the field of both conventional and organic farming, integrated crops and good agricultural practices is of great importance due to their advantages. Plant-specific pesticides obtained from plants do not have additional toxic substances due to their presence in nature. Biopesticides do not cause soil and water pollution as decomposed in a short time and do not form residue on the products. ${ }^{3}$

The subject that host selection by phytophag pests plays an important role in secondary plant compounds has increased the interest in nutritional inhibitory studies of pests. Hundreds of plant compounds have feeding inhibitory effects. ${ }^{4}$ Warthen \& Morgan ${ }^{5}$ listed more than 400 plants with feeding inhibitory properties. In this area, the most research were carried out on Azadirachta indica (A. Juss). ${ }^{6}$ In recent, there are commercial product developed from A. indica such as Margosan-O, Azatin, Bioneem, Neemguard, Neem Azal T / S. Later studies, the active ingredient is capsicin, Albanian pepper extract were developed into a preparation. This extract has been used to control so many pests such as aphids, thrips and red spiders, white flies in greenhouse and field conditions. ${ }^{3}$ There are many studies have been carried out in search of alternative to chemical pesticides In Turkey and studies are still going on. However, no studies have been conducted on the formulation of plant extracts. There is no biopesticide recommended to the application and there is a problem in this regard. Especially in organic agriculture, there is a great need for environmentally friendly and residue-free preparations. In Turkey, there are no biopesticides available for each product, and all recommended biopesticides are of international origin. Due to its rich plant flora studies carried out with plant extracts are important in Turkey. Biopesticides derived from local sources and plant origin substances are important to organic agriculture, integrated crops, good agricultural practices and national economy. Therefore, this study was conducted to prepare the formulation of two plant extracts $(A$. sallivum and M. azederach) and determine their effect on M. persicae.

\section{Material and method}

\section{Plants}

Allium sativum L. (Amaryllidaceae), was provided from Kastamonu and Melia azedarach L. (Meliaceae) was collected from Adana provinces in 2016. Fruits of both plants were used to prepare extract. 


\section{Preparing the extracts}

Fruits collected for extract preparation were dried for 3-4 days without being exposed to sunlight and then ground with mill. Dried fruit weighing $100 \mathrm{~g}$ were placed into the flasks. Then ethanol $(99.9 \%$ purity) were added to flasks with 1:8 (w/v) ratio. The samples were extracted with a direct solvent under reflux in a water bath set at $60^{\circ} \mathrm{C}$ for two hours. At the end of two hours. The extract was filtered through a filter paper and then taken out of the flask balloon. Ethanol was added to the remaining part with the same ratio $1: 8(\mathrm{w} / \mathrm{v})$ and extracted for another two hours in a water bath set at $60^{\circ} \mathrm{C}$ for complete extraction of phenolic components. After two hours the second extract was filtered through a filter paper to the same glass balloon. The solvent of the extract was evaporated to dryness in a vacuum rotary evaporator at $60^{\circ} \mathrm{C}$. $^{7}$ Three-five grams of extract were obtained from a total of $100 \mathrm{~g}$ of dry matter.

\section{Formulation preparation of extracts}

The solubility of the extract with the appropriate solvents was determined based on the physicochemical properties of the components contained in the extract. Determination of suitable solvent carried out according to Flanagan ${ }^{8}$ method to prepare formulation of extracts. According to this, $1.20 \mathrm{~g}$ extract was weighed and the test tube and 2 parts oil volume were taken. Water or suitable solvents were added in the form of a maximum of $10 \mathrm{ml}$ of water. The test tube was heated and mixed in a magnetic stirrer. Later, if the amount of added solvent reached $10 \mathrm{ml}$ and no dissolution occurred, the old solvent was removed from the experiments and another solvent was tried. In this way, different vegetable oils (soybean, sesame, sunflower, corn, rapeseed and canola oil) were used as solvent. The most suitable solvent was chosen to dissolve the extract and the most suitable formulation type was chosen. The extract was mixed at $800 \mathrm{rpm}$ in a vertical mixer with a suitable solvent and common formulas, considering the physical and chemical properties of the extract. The mixture was then mixed in a high-speed vertical mixer for 1.5 hours at $4500 \mathrm{rpm}$ until the fineness reached 10-20 microns and a homogeneous dispersion was obtained. Thus, a homogeneous distribution of the insoluble components in the extract was achieved. The products taken into the resting tank were kept for 24hours and subjected to quality control analysis.

\section{Quality control analysis}

The quality control tests were applied to the Suspension Concentrate (SC) formulation (as recommended by the Food and Agriculture Organization of the United Nations (FAO) and the World Health Organization (WHO) were as (Aspect, Specific Gravity (Density), Wet Sieve Test (CIPAC MT 185), Suppressibility (CIPAC MT 184) and Viscosity. ${ }^{9}$

\section{Doses mortality tests}

M. persicae: Discs cut from the leaves of eggplants ( $3 \mathrm{~cm}$ diameter) were dipped for 3-5 second with various doses of the extract. These discs were and 10 adults of M. pesicae were placed in each petri dish. ${ }^{10}$ Doses of 3. 5.7 and $10 \mathrm{ml} / 1$ liter of the extracts formulated were tested. Doses were prepared with distilled water and only distilled water was used for control. TritonX.100 was added as spreading and adhesive to distilled water. Also control only distilled water and TritonX.100 was used. Applications were conducted to adults of 1-3 days and trials were established with 6 replications. Clip-on petri dishes $(3.5 \mathrm{~cm}$ in diameter) were used to prevent the escape of adults of $M$. persicae. Counts were carried on the sixth day and the individuals died were recorded.
Test pant Eggplant and bean plant were grown in the climate room and greenhouse. All experiments were carried out in a climate cabin, which has temperature of $25 \pm 1^{\circ} \mathrm{C}$. Relative humidity of $60 \pm 5 \%$, day length of 16 hours.

\section{The experiment of greenhouse}

For experiments, pepper seedlings were planted in greenhouse on July 2017. The experiment was established with randomized plot design with four replications. Each parcel had got five plants. When pepper plants became 3-4-leafed, each plant was infested with $M$. persicae grown in the laboratory. Applications were made on the 10th of September in 2017 when the aphid population density reached 2025 live per leaf (nymph+adult / leaf). Spraying was carried out small hand sprayer. The amount of water was determined by calibration before application. In the counts the population density of M. persicae the lower. middle and upper leaves was considered and the level of $M$. persicae on the leaf was estimated and recorded by giving a class value in order to represent the population by observing the parcels before each count. 0-6 scale was used in the counts (Table 1). After the class value was given to the leaves taken from the parcel, the number of leaves entering each class was multiplied by the grade and the value found was divided by the total number of leaves and the index values were determined. The effect was determined with index values. After application 1, 3 and 7days counts were conducted.

Table I 0-6 scale was used in counts on greenhouse experiment

\begin{tabular}{llll}
\hline \multirow{2}{*}{$\begin{array}{l}\text { Class } \\
\text { Infection degree) }\end{array}$} & \multicolumn{2}{l}{ Number of aphid } & \\
\cline { 2 - 3 } & $\begin{array}{l}\text { Lower } \\
\text { limit }\end{array}$ & $\begin{array}{l}\text { Upper } \\
\text { limit }\end{array}$ & \\
\hline 0 & 0 & 0 & 0 \\
1 & 1 & 2 & 2 \\
2 & 3 & 10 & 7 \\
3 & 11 & 30 & 20 \\
4 & 31 & 100 & 70 \\
5 & 101 & 300 & 200 \\
6 & 301 & 1000 & 700 \\
\hline
\end{tabular}

\section{Statistical analysis}

Abbott formula ${ }^{11}$ was used to calculate insecticidal effect. Data were evaluated by analysis of variance and the mean values were compared by Duncan's test calculated by the program SPSS 20.6. The formula Henderson-Tilton ${ }^{12}$ study was used to determine the insecticidal effect for greenhouse data. The total number of leaves divided M. persicae, after the count value of the leaves taken from the plot. The number of sheets entered into each class and the value found in the class and the index values were found.

\section{Results and discussion}

\section{Quality control analysis}

Extract formulations prepared as Suspended Concentrate (SC) were subjected to quality control tests. These tests were appearance, specific gravity, suspension ability and fineness. Viscosity tests could not be conducted since sufficient number of samples not is taken. 
The formulation of $A$. sativum and M. azedarach had brownish black liquid appearance. It was revealed that the specific weight (density) was $1,050 \mathrm{~g} / \mathrm{ml}$. Suspension ability (CIPAC MT 184) results were $100 \%$; (WHO) was found to pass completely through the 75 -micron electrode.

\section{Dose-mortality test}

The results obtained from the studies carried out with the $M$. azederach and A. sativum plant extracts prepared in the formulation are given in Table 2. The highest effect was with the highest dose of both plant extracts. The extract of $M$. azederach showed higher effect than A. sativum. The effect also increased with increasing dose. It is determined that the difference between doses was significant in statistical analysis. All doses were in different groups $(\mathrm{F}=1.469$, $\mathrm{P}=0.00$ )

Table 2 The insecticidal effects (\%) of extracts of two different plants on Myzus persicae induced by leaf dipping methods

\begin{tabular}{lll}
\hline $\begin{array}{l}\text { Con. } \\
(\mathrm{ml} / \mathrm{L})\end{array}$ & Melia azederach & Allium sativum \\
\hline Effect $(\%)$ & $($ Mean $\pm \mathrm{E}) *$ & \\
\hline $\mathrm{I}$ & $20.37 \pm 3.45 \mathrm{e}$ & $15.56 \pm 1.99 \mathrm{e}$ \\
3 & $38.52 \pm 3.14 \mathrm{~d}$ & $20.74 \pm 3.46 \mathrm{~d}$ \\
5 & $66.48 \pm 3.45 \mathrm{c}$ & $42.59 \pm 5.54 \mathrm{c}$ \\
7 & $75.55 \pm 1.79 \mathrm{~b}$ & $63.15 \pm 3.4 \mathrm{lb}$ \\
10 & $94.33 \pm 2.55 \mathrm{a}$ & $79.30 \pm 2.02 \mathrm{a}$ \\
\hline
\end{tabular}

*Means within rows followed by the same uppercase letter are not significantly different (Duncan's multiple range test).

\section{Greenhouse experiment}

The results were given in Tables 3. As shown in Table 4, the highest dose of $M$. azederach showed that the highest effect occurred in as compared that of A. sativum at the last count. The smallest effect was determined that at the lowest dose of extract of A. sativa on day one. In the statistical analysis, it was determined that all values obtained in all three counts in the second and third doses were in the same group. Positive control showed higher effect than two extracts $(\mathrm{F}=25.149$, $\mathrm{P}=0.00)$. The efficacy of formulations prepared extracts of $M$. azedarach and A. sativum plants were investigated under laboratory and greenhouse conditions on $M$. persicae. In the laboratory studies, the dose of the extracts showing an effect of more than $75 \%$ and the two top doses were determined under biological conditions. As a result of the study, it was determined that plant extracts plant extracts formulated showed a medium effect of $80 \%$ or more under the greenhouse conditions. The formulations of $M$. azedarach and A. sativum plants extracts had average effect of $80 \%$ or more under greenhouse conditions on $M$. persicae. Capinera who studied about effect of extract of $M$. azedarach on $M$. persicae determined that methanol fruit extract of $M$. azedarach had rate mortality, repellent effect $100 \%$ at $25,12.5 \%$ and $1.25 \%$ concentrations on $M$. persicae, Aphis gossypii and Aphis fabae. It was demonstrated that neem tree seed extract showed repellent effect in adults and larvae and could not form colony on $M$. persicae. ${ }^{13}$ Pavela ${ }^{14}$ reported that some plant extracts (Azadirachta indica Juss. (Meliaceae). Chrysanthemum cinerariifolium (Asteraceae) and Pangomia glabra (Leguminosae)] showed mortality rate $100 \%$ at the highest concentration on $M$. persicae. In addition, extract of Pangomia glabra had the highest effect 12 days after application on M. persicae. A. sativum plant extract had repellent effect on $M$. persicae and cannot form colony. In another study carried out with garlic plant extract in both laboratory and field conditions, the extract had highly toxic and showed significant antifeeding effect on M. persicae. ${ }^{15}$ Erdogan ${ }^{16}$ revealed that the extract A. sativum had the highest mortality rate on nymphs and adults of $M$. persicae in both leaf dipping and spraying method. The commercial product Neem Azal T/S is the effective on M. persicae, and is used in many countries to control different pest.

The extracts of $M$. azedarach and A. sativum were formulated and recommended to control some pests. M. azedarach and A. indica belong to the same family and contain the same substances. ${ }^{17}$ The most studied plant as an insecticide is $A$. indica. The azadirachtin substance is obtained by drying leaves, bark and powder, fruit or seed oil from seed from A. indica. Azadirachtin is terpenoid structure and has different mechanisms of action on insects such as repellent insects, growth and growth inhibition, feeding inhibitor, fertility reducing, deterrence oviposition, insecticide and acaricide. There are so many literatures about effect azadirachtin on insects as formulated. For example, the study conducted by Bollhalder \& Zuber ${ }^{10}$ was reported that commercial product Neem Azal T/S were acaricidal effect both larvae and adult on $M$. persicae. Neem Azal T/S was used so many countries to control pests. Before applying 12 days different neem formulations [Azadirachtin-A (AZA-A 51\% plant oil)] showed the high mortality and had systemic effect of extract on A. fabae. Neem Azal $\mathrm{T}$ and Neem Azal T/S commercial products showed higher effect than pyretrum on Dysaphis devecta in the field conditions ${ }^{18}$ The product of Neem Azal-T/S significantly reduced the number of $M$. persicae. Neem Azal-T/S had the best control of M. persicae and were safe on its predators. ${ }^{19}$

Garlic, which has a rich composition, was evaluated in terms of different biological activities. Garlic extracts contain monopertenes, phenols and sesquiterpenes..$^{20}$ There are a few studies on the effect of formulated garlic extract on pests. Kazem \& Fraghaly ${ }^{21}$ prepared the formulation of extract of hot pepper, ginger and garlic by using linseed boiled oil. These formulated extracts were efficacy on Bemisia tabaci (Gennadius) (Hem.:Aleyrodidae) by the same authors. ElSherif \& Kazem ${ }^{22}$ found that formulated capsicum xylene extract was the effect on T. urticae. Kazem and El-Sherif prepared the formulation of EC of garlic extract and revealed that showed effect of acaricidal and insecticidal the formulated garlic extract on T. urticae and Aphis gossypii Glover (Hem.:Aphididae). Garlic leaf agglutinin is toxic to sap-sucking like cotton and pea aphids, and some caterpillars. Garlic leaf agglutinin is lectin related protein that is highly antinutritional and toxic to same insects such as the rice brown plant hopper, green leaf hopper, chickpea aphid, mustard aphid and other hemipteran insects. ${ }^{23}$ The insecticidal effect of formulated $M$. azedarach and $A$. sativum extracts was determined on $M$. persicae in laboratory and the greenhouse conditions. The studies of extraction and formulation were conducted pilot scale in the laboratory conditions. It is thought that more studies are needed to develop the formulation method. ${ }^{24}$ 
Table 3 The insecticidal effects of obtained from two different plants on Myzus persicae

\begin{tabular}{|c|c|c|c|c|}
\hline \multirow{3}{*}{ Treatments } & \multirow{3}{*}{$\begin{array}{l}\text { Doses } \\
(\mathrm{ml} / \mathrm{l})\end{array}$} & \multicolumn{3}{|l|}{ Count times } \\
\hline & & I st day (7.9.20 I 7) & 3rd day (9.9.20 I 7) & 7 th day $(15.9 .20 \mid 7)$ \\
\hline & & \multicolumn{3}{|l|}{ Effect (\%)(Mean $\pm E)$} \\
\hline \multirow{4}{*}{ Melia azederach } & 10 & $45.65 \pm 2.34 \mathrm{~b} \mathrm{C}$ & $55.87 \pm 3.49$ b B & $68.99 \pm 0.48$ b A \\
\hline & 15 & $73.77 \pm 2.8 \mathrm{I}$ bA & $80.21 \pm 2.69$ a A & $82.85 \pm 5.02$ b A \\
\hline & 20 & $85.64 \pm 1.44$ a A & $88.25 \pm 1.36$ a A & $90.33 \pm 1.75$ a A \\
\hline & 10 & $29.12 \pm 5.4 I$ с C & $39.45 \pm 6.10 \mathrm{~b} \mathrm{C}$ & $53.27 \pm 3.34$ b B \\
\hline \multirow[t]{2}{*}{ Allium sativum } & 15 & $44.45 \pm 3.86$ с B & $69.53 \pm 1.77$ a A & $75.85 \pm 1.67$ a A \\
\hline & 20 & $65.42 \pm 2.50$ a B & $73.29 \pm 3.43$ a A & $79.50 \pm 1.56$ a A \\
\hline Neem Azal T/S*** & 5 & $65.97 \pm 1.09 \mathrm{C}$ & $77.69 \pm 1.32 \mathrm{~B}$ & $92.8 \mathrm{I} \pm 2.26 \mathrm{~A}$ \\
\hline
\end{tabular}

*Means within rows followed by the same uppercase letter are not significantly different (Duncuns's multiple range test).

** Means within column followed by the same lowercase are not significantly different (Duncuns's multiple range test).

$* * *$ Positive control.

\section{Acknowledgements}

The authors thanks to General Directorate of Agricultural Research and Policies, Ministry of Agriculture and Forestry provide funds for this work.

\section{Conflicts of interest}

The author declares that there is no conflict of interest.

\section{References}

1. Petitt FL, Smilowitz Z. Green peach aphid feeding damage to potato in various plant growth stages. Journal of Economic Entomology. $1982 ; 75: 431-435$.

2. Smith AE, Secoy DM. Use of Plants in Control of Agriculture and Domestic Pests. Journal of Agricultural and Food Chemistry. $1975 ; 23: 1050$

3. U.S. Environmental Protection Agency. 2009.

4. Jacobson M. Plants Insects and man their interrelationships. Economic Botony. 1982;36:346-354.

5. Warthen JD, Morgan ED. Insect feeding deterrents.In: Morgan ED, Mandava NB, editors. CRC Handbook of Natural Pesticides. VI. Insect Attractants and Repellents. Boca Raton, Florida, USA. CRC Press; 1990.

6. Rembold DH, Sharma GK, Czoppelt CH, et al. Azadirachtin A potent insect growth regulator of plant origin. Zeitschrift für Angewandte Entomologie. 1982;93:12-17.

7. Brauer M. Davkota B. Control of Thaumatopoea piyocampa (Den.\&Schiff) by extracts of Melia azedarach L. (Meliaceae). Journal Applied Entomology. 1990;110:128-135.

8. Flanagan J. Principles of pesticide formulation. Industrial production and formulation of pesticides in devoloping countries. UN. Newyork. 1972;1(6):75-122.

9. Manual on development and use of FAO and WHO specifications for pesticides. 1st \& 3rd edn. 2016.

10. Bollhalder F, Zuber M. NeemAzal T/S against Myzus persicae. Proceedings at the 5th workshop. Wetzlar-Germany. 1996:141-145.
11. Abbot WS. A method of computing the effectiveness of an insecticide. Journal Economic Entomology. 1925;18(2):265-267.

12. Henderson CF, Tilton EW. Tests with acaricides against the brow wheat mite. Journal Economic Entomology. 1955;48:157-161.

13. Griffiths DC, Greenway AR, Lyoyd SL. The influence of repellent materials and aphid exracts on settling behaviour and larviposition of Myzus persicae (Sulzer). Bulletin of Entomological Research. 2009;68:613-619.

14. Pavela R. Effectiveness of Some Botanical Insecticides against Spodoptera littoralis Boisduvala (Lepidoptera: Noctuidae). Myzus persicae Sulzer (Hemiptera: Aphididae) and Tetranychus urticae. Plant Protection Science. 2009;45(4):161-167.

15. Lai R, You MS. Antifeedant and toxic activities of Allium sativum ethanol extracts against Myzus persicae (Sulzer). Journal of Fujian Agriculture and Foresty. 2010;39(1):15-18.

16. Erdogan P. Insecticide effect of Capsicum annuum L. (Solanaceae) and Allium sativum L. (Amaryllidaceae) extracts on Myzus persicae (Sulzer) (Hemiptera: Aphididae). Plant Protection Bulletin. 2015;55(4):305-315.

17. Oelrichs BP, Hill M, Vallely PJ, et al. Toxic Tetranortriterpenes of the fruit of Melia azedarach L. Phytochemistry. 1983;22(2):531-534.

18. Zuber M. NeemAzal-T/S against the rosy apple aphid field trials In Switzerland. Proceedings at the 5th workshop. Wetzlar-Germany. 1996:21-26.

19. El-Wakeil N, Said S, Saleh A. Effects of neem and diatomaceous earth against Myzus persicae and associated predators in addition to indirect effects on artichoke growth and yield parame. Archives of Phytopathology and Plant Protection. 2009;42(12):1132-1143.

20. Anwar A, Gould E, Tinson R, et al. Think Yellow and Keep Green of Sulfones from Garlic in Agriculture. Antioxidants. 2016;6 (1):3.

21. Kazem MGT, Farghaly SF. The role of Mixing Different Plant Extracts to Boiled Linseed Oil fort the control of Whitefly Bemisia tabaci. AmericanEurasian Journal Agricultural Environment Society. 2009;5(6):813-824

22. El-Shereif AEHN, Kazem MGT. The role of Capsicum and Garlic Xylene Extracts in Toxicity of Boiled Linseed Oil Formulations agains Cotton Leafworm. Egyptean Journal Applied Society. 2009;24(4A):308-319. 
23. Mondal HA, Chakraborti D, Majumder P, et al. Allergenicity assessment of Allium sativum leaf agglutinin, a potential candidate protein for developing sap sucking insect resistant food crops. PLOS ONE. 2011.
24. Digillio V, Cristofora M, Marchını DD, et al. Effects of a neem compound on the fecunditiy and longevity of Cerstitis capitata (Diptera:Tephritidae). Journal of Economic Entomology. 1999;92(1):76-82. 